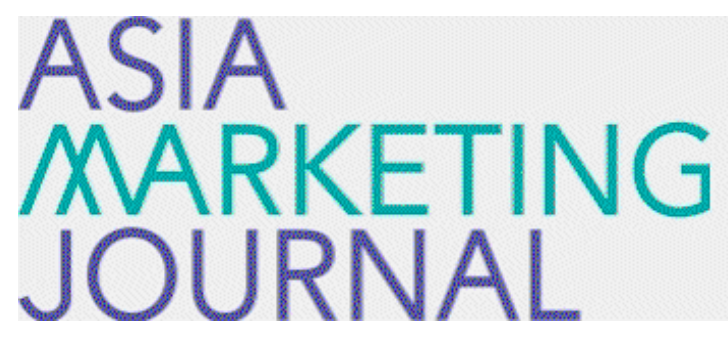

ASIA MARKETING JOURNAL

Volume 16 | Issue 4

Article 3

$1-31-2015$

\title{
The Contingent Effect of Marketing Alliances on Firm Profitability
}

Jongkuk Lee

Follow this and additional works at: https://amj.kma.re.kr/journal

Part of the Marketing Commons

\section{Recommended Citation}

Lee, Jongkuk (2015) "The Contingent Effect of Marketing Alliances on Firm Profitability," Asia Marketing Journal: Vol. 16 : Iss. 4 , Article 3.

Available at: https://doi.org/10.15830/amj.2015.16.4.19

This Article is brought to you for free and open access by Asia Marketing Journal. It has been accepted for inclusion in Asia Marketing Journal by an authorized editor of Asia Marketing Journal. 


\section{The Contingent Effect of Marketing Alliances on Firm Profitability*}

Forming interfirm collaborative relationships has become a key aspect of a firm's marketing strategies to create value for customers and achieve greater firm performance. While empirical findings are mixed in previous studies, this study is an effort to identify boundary conditions for the benefits of marketing alliances. We investigate internal and environmental factors that may magnify or constrain the effect of marketing alliances on firm profitability. Given the complementary relationship between marketing and R\&D activities, we focus on a firm's R\&D intensity as an internal factor that may magnify the value of marketing alliances for firm performance. For environmental factors, we focus on industry turbulence and industry competitiveness. Industry turbulence refers to the degree to which industry market conditions change quickly and unpredictably, whereas industry competitiveness refers to the degree to which a firm faces competition in the industry. By testing these factors, we are intended to reveal boundary conditions that determine the value of marketing alliances for firm profitability.

The analysis of firms in the diverse industries shows that while the main effect of marketing alliances on firm profitability is not significant, it becomes more positive when R\&D investment is more intensive or when industry environment is more turbulent. The results of this study imply that just forming more marketing alliances may not be enough to increase firm profitability. Our findings imply that marketing alliances become more effective in a dynamically changing industry environment. That is, firms can cope with industry uncertainties more effectively by forming marketing alliances. At the same time, the moderating effect of $R \& D$ intensity implies that the internal investments in R\&D magnify the effect of marketing alliances on firm profitability.

The findings of this study contributes to the existing alliance literature in three aspects. First, this study enhances our understanding of the contingent value of marketing alliances by testing both internal and external factors that may influence the effectiveness of marketing alliances. Second, this study responds to the need for research that investigates actual performance resulting from interfirm relationships. Third, while previous studies primarily focused on a specific industry, this study extend previous findings of the boundary conditions for the benefits of marketing alliances in a broader context.

Key words: marketing alliances, R\&D intensity, industry turbulence, industry competitiveness

\footnotetext{
* This work was supported by the National Research Foundation of Korea Grant funded by the Korean Government (NRF-2013S1A5A8023325)

** Assistant Professor of Marketing, Ewha School of Business, Ewha Womans University(jongkuk@ewha.ac.kr)
} 


\section{Introduction}

Collaborative interfirm relationships are vital aspects of a firm's marketing strategies to create value for customers and appropriate the created value in the market (Bucklin and Sengupta 1993; Jap 1999; Lin and Lin 2009). Firms are actively engaged in alliances for various marketing activities, such as sales, promotion, or distribution (Swaminathan and Moorman 2009; Venkatesh, Mahajan, and Muller 2000). However, we have only mixed findings regarding the value of marketing alliances for firm performance. On the one hand, studies have shown that marketing alliances facilitate access to marketing resources and enhance a firm's financial performance, such as profitability or firm value (Bello, Katsikeas, and Robson 2010; Houston and Johnson 2000; Jap 1999). On the other hand, some studies have found no significant effect of marketing alliances on firm performance (e.g., Anand and Khanna 2000; Das, Sen, and Sengupta 1998; Koh and Venkatraman 1991). Therefore, further research efforts are necessary to examine the boundary conditions for marketing alliances to have an impact on performance, i.e., when marketing alliances create value for firm performance and when they fail to do so (Swaminathan and Moorman 2009).

This study is an effort in this direction to understand when and how the marketing alli- ances help a firm enhance its performance. We investigate the internal and environmental factors that may amplify or mitigate the effect of marketing alliances on firm profitability. Specifically, we examine two factors that may influence the effectiveness of a firm's marketing alliances; a firm's internal resources that complement such externally gained marketing resources and industry environment that affects the need for externally gained marketing resources.

Given the complementary relationship between marketing and R\&D activities (King, Slotegraaf, and Kesner 2008; Moorman and Slotegraaf 1999), we focus on a firm's R\&D intensity as an internal factor that may magnify the value of marketing alliances for firm performance. For external environmental factors, we focus on industry turbulence and industry competitiveness. Industry turbulence refers to the degree to which industry market conditions change quickly and unpredictably (Fang, Palmatier, and Steenkamp 2008), whereas industry competitiveness refers to the degree to which a firm faces competition in the industry (Cui, Griffith, and Cavusgil 2005). The uncertainty and competition among firms in a given industry pose significant challenges that a firm should overcome to achieve greater performance, and marketing alliances will become more critical in such a demanding environment. By testing these factors, we attempt to reveal the boundary conditions that determine the value of marketing alliances for firm profitability. We rely on ROA (return on 
assets) for firm profitability as it indicates how a firm uses its assets effectively to generate profits.

The analysis of firms in the diverse industries shows that while the main effect of marketing alliances on firm profitability is not significant, it becomes more significantly positive when R\&D investment is more intensive and in a more turbulent industry environment. The results of this study imply that simply forming more marketing alliances may not be enough to increase firm profitability. These findings show that the internal investments in R\&D magnify the effect of marketing alliances on firm profitability. At the same time, forming marketing alliances is more effective in a dynamically changing industry environment. That is, firms can cope with industry uncertainties more effectively by forming more marketing alliances.

The findings of this study contributes to the existing alliance literature in three aspects. First, this study enhances our understanding of the contingent value of marketing alliance by testing both internal and external factors that may influence the effectiveness of marketing alliances. Second, this study responds to the need for research that investigates actual performance resulting from interfirm relationships (Kalaignanam, Shankar, and Varadarajan 2007). Third, while previous studies primarily focused on a specific industry, such as biotechnology and pharmaceutical industries (Swaminathan and Moorman 2009; Wuyts, Dutta, and Stremersch 2004), this study extends previous findings of the boundary conditions for the benefits of marketing alliances in a broader context.

In the next section, we review previous studies related to marketing alliances and their financial performance implications. We then present a set of hypotheses regarding the boundary conditions for the effect of marketing alliances on firm profitability. After describing research context, variables, and research methods for this study, we present the results of this study. Finally, we conclude this study by discussing the implications of our findings.

\section{Literature Review}

Previous studies have extensively examined the interfirm relationships for various marketing activities, such as product distribution and sales, product promotion, or product development with customer firms (Swaminathan and Moorman 2009). Specifically, researchers have examined various factors that affect the effectiveness of interfirm relationships, such as power distribution between partners, partner match or conflict, control mechanism, idiosyncratic investment for partners, and coordination effort between partners (e.g., Anderson and Barton 1992: Bucklin and Sengupta 1993; Dwyer and Oh 1987; Jap 1999). Studies have also shown 
that cooperative relationships with customers contribute to successful new product development in terms of development speed and innovativeness (Bonner and Walker 2004; Fang 2008). From these aspects, previous studies have suggested that marketing relationships contribute to a firm's financial performance (Houston and Johnson 2000; Jap 1999; Luo, Rindfleisch, and Tse 2007). For instance, Jap (1999) showed that marketing alliances in a distribution channel enhance the profit performance of firms through coordination and idiosyncratic investment. Overall, previous studies have shown that marketing alliances can improve firm performance when they are effectively managed.

However, other studies have found no significant effect of marketing alliances on firm value in the market. Whereas $R \& D$ alliances have consistently been shown to have a significant positive impact on firm value, empirical findings on the effects of marketing alliances are mixed (Das, Sen, and Sengupta 1998; Koh and Venkatraman 1991). In response to these mixed findings, recent research has examined boundary conditions, i.e., when and how firms would benefit from forming more marketing alliances. For instance, Swaminathan and Moorman (2009) showed that the firm value gained from forming a new marketing alliance is contingent upon network characteristics of alliance partners, i.e., a firm's position in the network of interfirm relationships in the industry.

However, our understanding of marketing alliances are limited in three aspects. First, given the importance of marketing alliances in implementing a firm's marketing strategies, we need to examine more diverse factors that magnify or suppress the benefits of marketing alliances. In response, we further examine a firm's internal and external factors that may influence the effectiveness of marketing alliances. Second, while prior research has been focused on firm value gains in the stock market, which reflect the expectations of firm performance in the future, the need for looking at the actual performance has been pointed out (Kalaignanam, Shankar, and Varadarajan 2007). Given the importance of firm profits as a performance indicator (Bae and Gargiulo 2004; Lavie and Miller 2008), we therefore examine firm profitability as an outcome resulting from marketing alliances. Third, while the biotechnology and pharmaceutical industries that the previous studies have focused on are of great importance (Swaminathan and Moorman 2009; Wuyts, Dutta, and Stremersch 2004), there is a need to extend previous findings and generalize the boundary conditions for the benefits of marketing alliances in a broader context. In response, we empirically test in the diverse high-tech industrial contexts, which include semiconductors, computers, telecommunication equipments, and software industries. 


\section{Hypotheses}

Figure 1 presents a conceptual framework for this study. We first propose the direct effect of forming more marketing alliances on firm profitability as a baseline hypothesis. We then propose both internal and external factors that can moderate the direct effect, that is, boundary conditions for the benefits of forming more marketing alliances. First, given the complementary relationship between marketing and R\&D activities (King, Slotegraaf, and Kesner 2008; Moorman and Slotegraaf 1999), we focus on a firm's R\&D intensity as an internal factor that may magnify the value of marketing alliances for firm performance. Second, firms tend to have a greater need for resources in a high level of uncertainty or competition (Jaworski and Kohli 1993). For external environmental factors, we therefore focus on industry turbu- lence, which refers to the degree to which industry market conditions change quickly and unpredictably (Fang, Palmatier, and Steenkamp 2008), and industry competitiveness, which refers to the degree to which a firm faces competition in the industry (Cui, Griffith, and Cavusgil 2005). By testing these factors, we attempt to reveal the boundary conditions that determine the value of marketing alliances for firm profitability.

\subsection{Effect of marketing alliances on firm profitability}

Marketing alliances contribute to the downstream value chain activities, i.e., the process of appropriating value in the marketplace (Bucklin and Sengupta 1993; Ellegaard, Medlin, and Geersbro 2014; Jap 1999; Venkatesh, Mahajan, and Muller 2000). First, building marketing alliances speeds up consumer acceptance of new

〈Figure 1〉 Conceptual Model

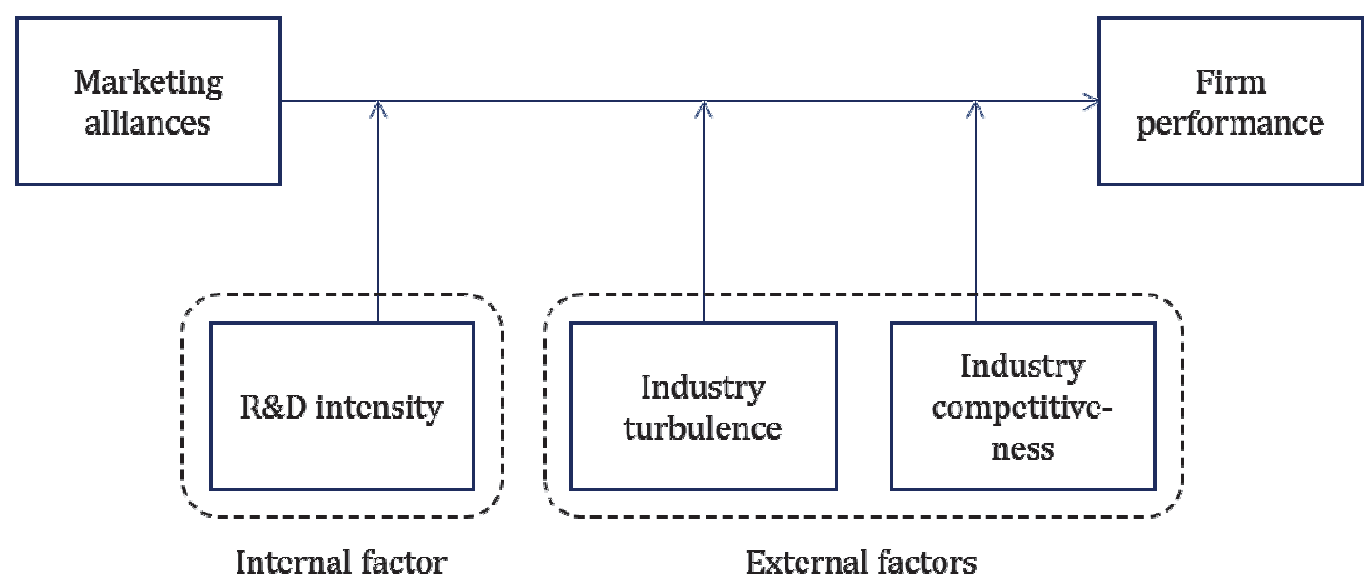

The Contingent Effect of Marketing Alliances on Firm Profitability 23 
products as it becomes a signal of the quality of new products in the presence of consumers' uncertainty about the new products (Podolny 2001). For instance, forming alliances with partners of well-known brands amplify or build the user awareness of products (Dickinson and Heath 2006). Second, marketing alliances provide the expanded distribution channel and lower the overall distribution cost. That is, marketing alliances create the economies of scale and scope to deploy products in the presence of market competition (Hagedoorn 1993). Third, marketing alliances also allow a firm to use its partners' marketing infrastructure, such as procurement and distribution channels or sales forces to enter into new markets (Lavie and Miller 2008). Thus, building more marketing alliances has been suggested to enhance firm performance by facilitating the appropriation of value in a timely and cost-effective manner. These previous findings indicate that building marketing alliances is a source of competitive advantage and contributes to profit and firm profitability (Swaminathan and Moorman 2009). As a baseline hypothesis, we therefore propose a positive effect of marketing alliances on firm profitability.

H1: A firm's marketing alliances will increase the profitability of the firm.

\subsection{Moderating effects of internal factor: $R \& D$ intensity}

We propose that $R \& D$ intensity will magnify the benefits of forming marketing alliances for firm profitability for the following two reasons. First, market inputs have critical roles in facilitating innovations at the upstream of the value chain (Moorman and Slotegraaf 1999; Song et al. 2005). As such, market information gained from marketing alliances can enhance the effectiveness of internal R\&D investment, facilitating market-driven innovations (Fabrizio and Thomas 2012). Second, by forming marketing alliances, firms gain marketing capability for appropriating innovations in the market. A firm internally investing in R\&D will have more innovations and new products that can be exploited and leveraged through the marketing alliances with partners that have expertise in the distribution, sales, or promotion of new products. In particular, previous marketing studies have shown that innovative firms, in spite of their technological success, frequently fail in the market (Golder and Tellis 1993; Sivadas and Dwyer 2000). That is, R\&D investment in developing new products is accompanied by a high level of market uncertainty. The role of marketing alliances in successfully commercializing new products will become more critical under these risky and uncertain conditions caused by R\&D investment. Therefore, the value of marketing alliances for generating firm profit 
will become more critical when combined with more intensive R\&D investment. With these two reasons, we expect that the effect of forming marketing alliances on firm profitability will become stronger as the firm invests more in R\&D. Namely, firms investing more in R\&D will benefit more from forming marketing alliances.

H2: R\&D intensity will positively moderate the effect of marketing alliances on firm profitability.

\subsection{Moderating effects of external factors: industry turbulence and competitiveness}

\subsubsection{Industry turbulence}

Industry turbulence refers to the rate of changes in customer demands and preferences in a given industry (Jaworski and Kohli 1993). The turbulent environment can destruct swiftly the relevance and value of market information, resource, and capability that a firm has previously built up (Jaworski and Kohli 1993). Forming new marketing alliances will not only allow a firm to access new capabilities which would make the firm stay relevant in the dynamically changing environment, but also facilitate consumer acceptance of new products. By relying on its partners' marketing infrastructure, such as procurement, distribution channels, or sales forces, a firm may avoid the potential risks associated with investment in marketing infrastructure more effectively, and have greater flexibility in entering into new markets in the uncertain environment (Lavie and Miller 2008). We therefore predict that forming marketing alliances will become more valuable in the turbulent environment than in the stable environment. That is,

H3: Industry turbulence will positively moderate the effect of marketing alliances on firm profitability.

\subsubsection{Industry competitiveness.}

In a competitive industry environment, a firm's market performance, such as market share or profits, are more directly affected by their competitors (Jaworski and Kohli 1993; Kohli and Jaworski 1990). Firms therefore tend to pay a considerable attention to their competitors and respond to the competitors' moves promptly when they introduce new products or change prices (Grewal and Tansuhaj 2001). Marketing alliances such as distribution channel, branding, or promotions can act as a mechanism for a firm to defend its ground in the markets from the competitors. Forming marketing alliances with partners, firms can pool their respective resources and hedge against the competitive threats. We therefore propose that marketing alliances will become more beneficial in a more 
competitive industry environment.

H4: Industry competitiveness will positively moderate the effect of marketing alliances on firm profitability.

\section{Research Methodology}

\subsection{Research context and data collection}

We tested the hypotheses using data collected from a variety of industries, which include industrial and commercial machinery and computer equipment industry (SIC code 35), electronic and other electrical equipment and components (SIC code 36), computer programming, data processing, and other computer related services (SIC code 737). Firms in these industries extensively build collaborative relationships with various partners (Kale, Dyer, and Singh 2002). Thus, the selected industries provide an ideal context to examine how a firm's marketing alliances affect firm profitability. We collected data from a variety of secondary sources, including COMPUSTAT for financial information and SDC Platinum for alliance information.

We first listed publicly traded firms from COMPUSTAT database between 1991 and 2005 in the selected industries. We then collected alliance information of those firms from
SDC Platinum database from 1991 to 2005. Finally, we get financial information of firms from COMPUSTAT database. We used the first five-year (i.e., 1991-1995) alliance data to measure marketing alliance portfolio in 1995 and one year lag to estimate firm profitability. After observations with missing variables were eliminated, the dataset for this study contained 1,667 yearly observations from 232 firms over 1996 - 2005. Among these 232 firms, we have 60 firms from industrial and commercial machinery and computer equipment industry (SIC code 35), 91 firms from electronic and other electrical equipment and components (SIC code 36), 43 firms from Computer Programming, Data Processing, and Other Computer Related Services (SIC code 737), and the remaining 39 firms from other diverse industries including transportation, measuring, analyzing, and controlling instruments, and other service industries.

\subsection{Variables}

\subsubsection{Firm profitability}

We used ROA (Return on Assets) to measure the profitability of firms. ROA is widely used to evaluate annual operations, that is, how a firm uses its assets to generate earnings (Bae and Gargiulo 2004; Lavie and Miller 2008). We measured a firm i's ROA in year $t$ by the net income of firm $i$ in year $t$ divided by its total assets in year $t$. 


\subsubsection{Marketing alliances}

SDC platinum database classifies various functional activities for which firms form alliances. The functional activities include R\&D, manufacturing, supply, marketing, and retail and wholesale services among others. Among them, we defined alliances specifically targeting marketing service or retail and wholesale service as marketing alliances. Consistent with previous studies (Stuart 2000), we used a 5-year window to measure marketing alliance portfolio size. We measured the firm i's marketing alliances in year $t$ by the number of alliances that firm $i$ formed for such functional activities as marketing service or retail and wholesale service in year $t-4$ to year $t$. We also used $4-$ and 6 -year windows to check the robustness of the empirical tests regarding the time window used to measure marketing alliances.

\subsubsection{Industry turbulence, industry competitiveness, and $R \& D$ intensity}

A method commonly used to measure industry turbulence is to calculate the variation of industry sales volume (Fang, Palmatier, and Steenkamp 2008). We measured industry turbulence by calculating the standard deviation of sales in the firm's primary industry across the preceding five years, and then divided it by the average industry sales for those years. For industry competitiveness, we first calcu- lated the degree of industry concentration by using Herfindahl index of firm sales within each industry (4-digit SIC code). We measured industry competitiveness by 1 - industry concentration (Fang, Palmatier, and Steenkamp 2008). To measure R\&D intensity, we took the firm's R\&D expenditure, divided by its total assets (Lavie and Miller 2008).

\subsubsection{Control variables}

We controlled the effect of internal resources on firm profitability by including firm size. We measured firm size by total assets with a log transformation (Kalaignanam, Shankar, and Varadarajan 2007; Lee 2011). We also included year dummies to control for industry-wide yearspecific effects on firm profitability. We also control for firm-level heterogeneity by using the fixed-effects model as discussed blow.

\subsection{Model}

We first applied Hausman's (1978) test to determine whether unobserved effects should be modeled as fixed or random effects, and the Hausman test results indicated a statistically significant difference between the estimated parameters between the two models $(p<$ 0.001). We therefore tested our model using a fixed-effects model, which controls for unobserved heterogeneity across the firms in a non-parametric way. To mitigate concerns about 
serial correlations of the error terms, which can deflate standard errors and inflate significance of estimated parameters, we checked for firstorder serial correlation (i.e., autocorrelation) in the errors by following Wooldridge's recommendation (2002). In our model, the hypothesis of no first-order serial correlation was rejected $(p<0.001)$, we therefore included an autoregressive (AR1) disturbance term. Equation (1) presents the model to be estimated to test the effect of forming more marketing alliances and how this effect is moderated by other factors.

(1) $\mathrm{ROA}_{i, t+1}=v+a_{i}+\beta_{1}$ Marketing Alliances $_{i t}+\beta_{2} \mathrm{R} \& \mathrm{D}$ intensity it $+\beta_{3}$ Industry Turbulence $i t+\beta_{4}$ Industry Competitiveness $_{i t}+\beta_{5} \mathrm{R} \& \mathrm{D}$ intensity $_{i t}$ * Marketing Alliancesit $+\beta_{6}$ Industry Turbulence $_{i t} *$ Marketing Alliances $_{i t}+\beta_{7}$ Industry Competitiveness $s_{i t} *$ Marketing Alliances $_{i t}+$ Control variables $+\varepsilon_{i t}$,

where $v$ is overall constant, $a_{i}$ is firm specific constant, and $\varepsilon_{i t}=\rho \varepsilon_{i t-1}+\mu_{i t}$ and $-1<\rho<1$, where $\rho$ is the autoregressive $\operatorname{AR}(1)$ parameter with a zero mean and $\mu_{i t}$ is homoskedastic and serially uncorrelated error term.

\section{Results}

Table 1 shows descriptive statistics of the variables and their correlations. In Table 2, we present the test results. Model 1 in Table 2 tests the mains effects of variables, and Model 2 tests moderating effects in a 5-year window. Models 3 and 4 show the results of robustness tests with marketing alliances in 4- and 6-year windows. Model 1 shows that marketing alliances have no significant effect on firm profitability $\left(\beta=0.000\right.$, n.s.), failing to support $H_{1}$. However, Model 2 shows that R\&D intensity positively moderates the effect of marketing alliances on firm profitability $(\beta=0.092, p<$ 0.001 ), in support of $\mathrm{H}_{2}$. Figure 2 illustrates the effects of marketing alliances on firm profitability depending on the level of R\&D intensity, in which we used one standard deviation above and below the mean for the high and low levels, respectively. Simple slope analysis (Aiken and West 1991) shows that when a firm's R\&D intensity is high, the effect of marketing alliances on firm profitability becomes positive $(\beta=0.028, p<0.01)$; however, it becomes negative when a firm's $R \& D$ intensity is low $(\beta=-0.008, p<0.01)$.

Model 2 also shows that industry turbulence positively moderates the effect of marketing alliances on firm profitability $(\beta=0.024, p<$ 0.01 ), in support of $\mathrm{H}_{3}$. Figure 3 illustrates the effects of marketing alliances on firm profitability depending on the level of industry turbulence. Simple slope analysis (Aiken and West 1991) shows that when the industry turbulence is high, the effect of marketing alliances 
〈Table 1〉 Descriptive statistics and correlations of variables

\begin{tabular}{|c|c|c|c|c|c|c|c|c|c|c|c|c|c|c|c|c|c|c|}
\hline Variables & Mean & Std. Dev. & 1 & 2 & 3 & 4 & 5 & 6 & 7 & 8 & 9 & 10 & 11 & 12 & 13 & 14 & 15 & 16 \\
\hline 1. $\mathrm{ROA}$ & 0.04 & 0.31 & 1.00 & & & & & & & & & & & & & & & \\
\hline 2. Marketing alliances & 5.21 & 13.89 & 0.08 & 1.00 & & & & & & & & & & & & & & \\
\hline 3. Industry turbulence & 0.19 & 0.13 & -0.09 & -0.04 & 1.00 & & & & & & & & & & & & & \\
\hline 1. R\&D irtensity & 0.11 & 0.27 & -0.23 & -0.05 & 0.03 & 1.00 & & & & & & & & & & & & \\
\hline 5. Industry competitiveness & 0.78 & 0.18 & 0.06 & -0.14 & 0.04 & 0.08 & 1.00 & & & & & & & & & & & \\
\hline 6. Firm size & 6.73 & 2.50 & 0.40 & 0.34 & -0.13 & -0.31 & -0.12 & 1.00 & & & & & & & & & & \\
\hline 7. Year 1996 & 0.12 & 0.32 & 0.06 & 0.09 & 0.00 & 0.01 & 0.01 & -0.11 & 1.00 & & & & & & & & & \\
\hline 8. Year 1997 & 0.11 & 0.32 & 0.01 & 0.07 & 0.00 & 0.02 & 0.01 & -0.08 & -0.13 & 1.00 & & & & & & & & \\
\hline 9. Year 1998 & 0.11 & 0.31 & -0.01 & 0.03 & 0.01 & 0.02 & 0.00 & -0.05 & -0.13 & -0.12 & 1.00 & & & & & & & \\
\hline 10. Year 1999 & 0.10 & 0.30 & 0.02 & -0.01 & -0.05 & 0.07 & 0.03 & -0.04 & -0.12 & -0.12 & -0.12 & 1.00 & & & & & & \\
\hline 11. Year 2000 & 0.10 & 0.30 & 0.00 & -0.02 & -0.03 & -0.02 & 0.02 & 0.02 & -0.12 & -0.12 & -0.11 & -0.11 & 1.00 & & & & & \\
\hline 12. Year 2001 & 0.10 & 0.30 & -0.08 & -0.03 & 0.10 & -0.01 & 0.01 & 0.05 & -0.12 & -0.12 & -0.11 & -0.11 & -0.11 & 1.00 & & & & \\
\hline 13. Year 2002 & 0.09 & 0.29 & -0.03 & -0.03 & 0.04 & -0.02 & 0.00 & 0.06 & -0.12 & -0.11 & -0.11 & -0.11 & -0.11 & -0.10 & 1.00 & & & \\
\hline 14. Year 2003 & 0.09 & 0.29 & 0.00 & -0.04 & 0.00 & -0.02 & -0.02 & 0.05 & -0.12 & -0.11 & -0.11 & -0.11 & -0.11 & -0.10 & -0.10 & 1.00 & & \\
\hline 15. Year 2004 & 0.09 & 0.29 & 0.01 & -0.04 & -0.04 & -0.03 & -0.04 & 0.06 & -0.12 & -0.11 & -0.11 & -0.11 & -0.11 & -0.10 & -0.10 & -0.10 & 1.00 & \\
\hline 16. Year 2005 & 0.09 & 0.28 & 0.02 & -0.04 & -0.02 & -0.03 & -0.03 & 0.07 & -0.11 & -0.11 & -0.11 & -0.10 & -0.10 & -0.10 & -0.10 & -0.10 & -0.10 & 1.00 \\
\hline
\end{tabular}


〈Table 2〉 The effect of marketing alliances on firm profitability (ROA)

\begin{tabular}{|c|c|c|c|c|c|c|c|c|c|}
\hline \multirow{3}{*}{ Marketing alliances } & \multirow{2}{*}{$\begin{array}{c}\text { Hypotheses } \\
\mathrm{H}_{1}\end{array}$} & \multicolumn{2}{|c|}{$\begin{array}{c}\text { Model } 1 \\
\text { (5-year windows) } \\
\end{array}$} & \multicolumn{2}{|c|}{$\begin{array}{c}\text { Model } 2 \\
\text { (5-year windows) } \\
\end{array}$} & \multicolumn{2}{|c|}{$\begin{array}{c}\text { Model } 3 \\
\text { (4-year windows) } \\
\end{array}$} & \multicolumn{2}{|c|}{$\begin{array}{c}\text { Model } 4 \\
\text { (6-year windows) } \\
\end{array}$} \\
\hline & & 0.000 & $(0.002)$ & -0.008 & $(0.006)$ & -0.002 & $(0.009)$ & -0.005 & $(0.005)$ \\
\hline & & $-0.048^{*}$ & $(0.021)$ & $-0.136^{* * *}$ & $(0.025)$ & $-0.046^{*}$ & $(0.021)$ & $-0.214^{* * *}$ & $(0.032)$ \\
\hline Industry turbulence & & $-0.386^{* * * *}$ & $(0.066)$ & $-0.433^{* * * *}$ & $(0.068)$ & $-0.437^{* * *}$ & $(0.069)$ & -0.436 **** & $(0.068)$ \\
\hline Industry competitiveness & & 0.212 & $(0.130)$ & 0.178 & $(0.133)$ & 0.207 & $(0.136)$ & 0.190 & $(0.131)$ \\
\hline $\begin{array}{l}\text { Marketing alliances } * \text { R\&D } \\
\text { intensity }\end{array}$ & $\mathrm{H}_{2}$ & & & $0.092^{* * * *}$ & $(0.015)$ & $0.059^{* * *}$ & $(0.019)$ & $0.084^{* * * *}$ & $(0.012)$ \\
\hline $\begin{array}{l}\text { Marketing alliances * Industry } \\
\text { turbulence }\end{array}$ & $\mathrm{H}_{3}$ & & & $0.024^{* * *}$ & $(0.008)$ & $0.026^{*}$ & $(0.011)$ & $0.021^{* * * *}$ & $(0.006)$ \\
\hline $\begin{array}{l}\text { Marketing alliances * Industry } \\
\text { competitiveness }\end{array}$ & $\mathrm{H}_{4}$ & & & -0.007 & $(0.009)$ & -0.010 & $(0.013)$ & -0.009 & $(0.007)$ \\
\hline Firm size & & $-0.032 *$ & $(0.015)$ & $-0.029 *$ & $(0.015)$ & $-0.028^{+}$ & $(0.015)$ & $-0.030^{*}$ & $(0.015)$ \\
\hline Year 1997 & & 0.058 & $(0.244)$ & 0.075 & $(0.246)$ & 0.046 & $(0.243)$ & 0.095 & $(0.252)$ \\
\hline Year 1998 & & 0.078 & $(0.349)$ & 0.095 & $(0.349)$ & 0.059 & $(0.348)$ & 0.120 & (0.353) \\
\hline Year 1999 & & 0.117 & $(0.394)$ & 0.138 & $(0.392)$ & 0.095 & (0.393) & 0.163 & $(0.393)$ \\
\hline Year 2000 & & 0.105 & $(0.414)$ & 0.133 & $(0.410)$ & 0.084 & $(0.414)$ & 0.159 & $(0.410)$ \\
\hline Year 2001 & & 0.055 & $(0.423)$ & 0.085 & $(0.418)$ & 0.035 & $(0.423)$ & 0.114 & (0.417) \\
\hline Year 2002 & & 0.064 & $(0.427)$ & 0.093 & $(0.422)$ & 0.043 & $(0.426)$ & 0.122 & $(0.420)$ \\
\hline Year 2003 & & 0.091 & $(0.428)$ & 0.119 & $(0.422)$ & 0.070 & $(0.428)$ & 0.148 & $(0.421)$ \\
\hline Year 2004 & & 0.091 & $(0.428)$ & 0.118 & $(0.423)$ & 0.069 & $(0.428)$ & 0.146 & $(0.421)$ \\
\hline Year 2005 & & 0.106 & $(0.429)$ & 0.133 & $(0.424)$ & 0.084 & $(0.429)$ & 0.161 & $(0.422)$ \\
\hline Constant & & 0.071 & $(0.233)$ & 0.074 & $(0.234)$ & 0.081 & $(0.232)$ & 0.054 & $(0.241)$ \\
\hline Observations & & 1667 & & 1667 & & 1667 & & 1667 & \\
\hline $\mathrm{R}^{2}$ (Within) & & 0.055 & & 0.082 & & 0.065 & & 0.088 & \\
\hline $\mathrm{R}^{2}$ (Between) & & 0.143 & & 0.121 & & 0.151 & & 0.093 & \\
\hline
\end{tabular}

Standard errors in parentheses

$+p<0.10,{ }^{*} p<0.05,{ }^{* *} p<0.01,{ }^{* * *} p<0.001$; Two-tailed test for all variables. 
〈Figure 2〉 Moderating Effect of R\&D Intensity

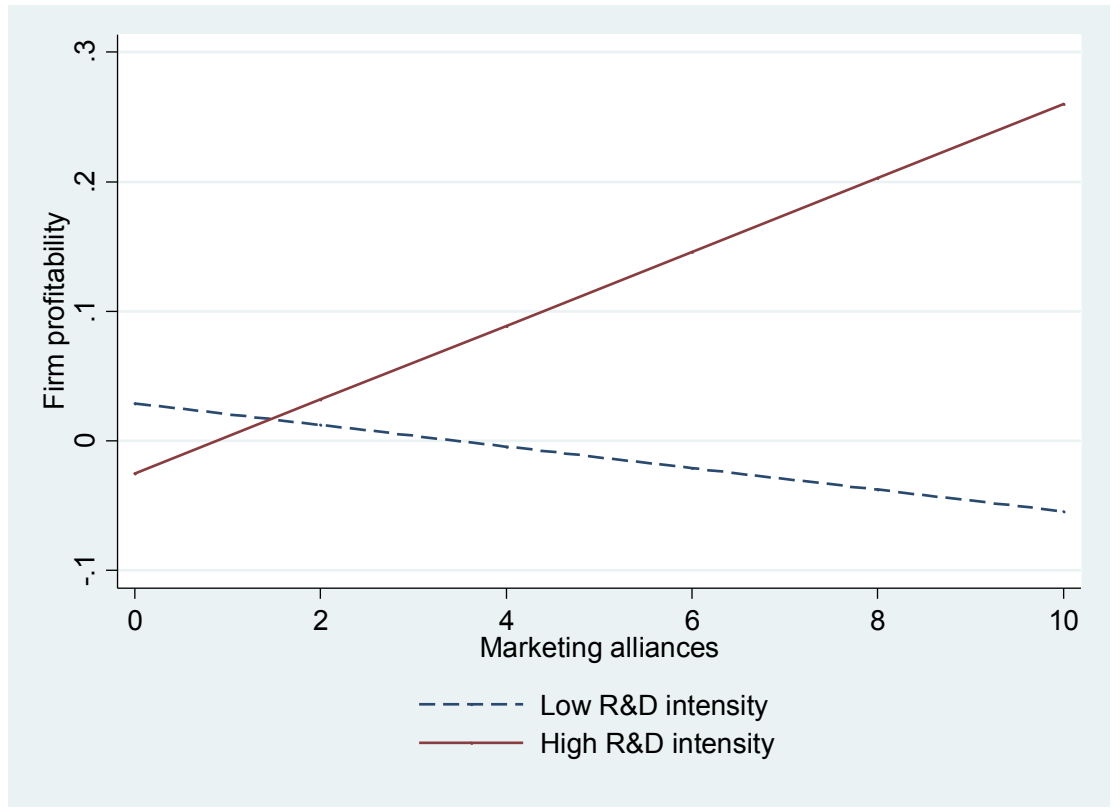

on firm profitability becomes positive ( $\beta=$ 0.007, $p<0.01)$; in contrast, when the industry turbulence is low, this effect becomes insignificant $(\beta=0.001$, n.s.). Finally, for the moderating effect of industry competitiveness, we found no significant effect ( $\beta=-0.007$, n.s.), failing to support $\mathrm{H}_{4}$. One possible explanation in that although we focused on the greater benefits of marketing alliances in a more competitive industry environment, there can also be the benefits of marketing alliances in a less competitive environment to preoccupy the market with a lower level of competitive intensity. Thus, industry competitiveness can have contrasting effects on the benefits of marketing alliances for firm performance.

We tested the robustness of the findings in
Models 3 and 4 using different windows, i.e., 4-year and 6-year window to create marketing alliances, and the estimation results are consistent with and confirm the findings of Model 2 , with minor differences. Regarding the moderating effect of industry turbulence, Model 3 shows that this effect becomes less significant in a 4-year window (from $p<0.01$ to $p<$ 0.05 ) and becomes more significant in a 6 -year window (from $p<0.01$ to $p<0.001$ ). Similarly, the moderating effect of R\&D intensity becomes less significant in a 4-year window (from $p<0.001$ to $p<0.01$ ). These additional tests confirm the robustness of the findings from this study. Overall, the results of this study support the main argument of this study that the effect of marketing alliances on firm 
〈Figure 3〉 Moderating Effect of Industry Turbulence

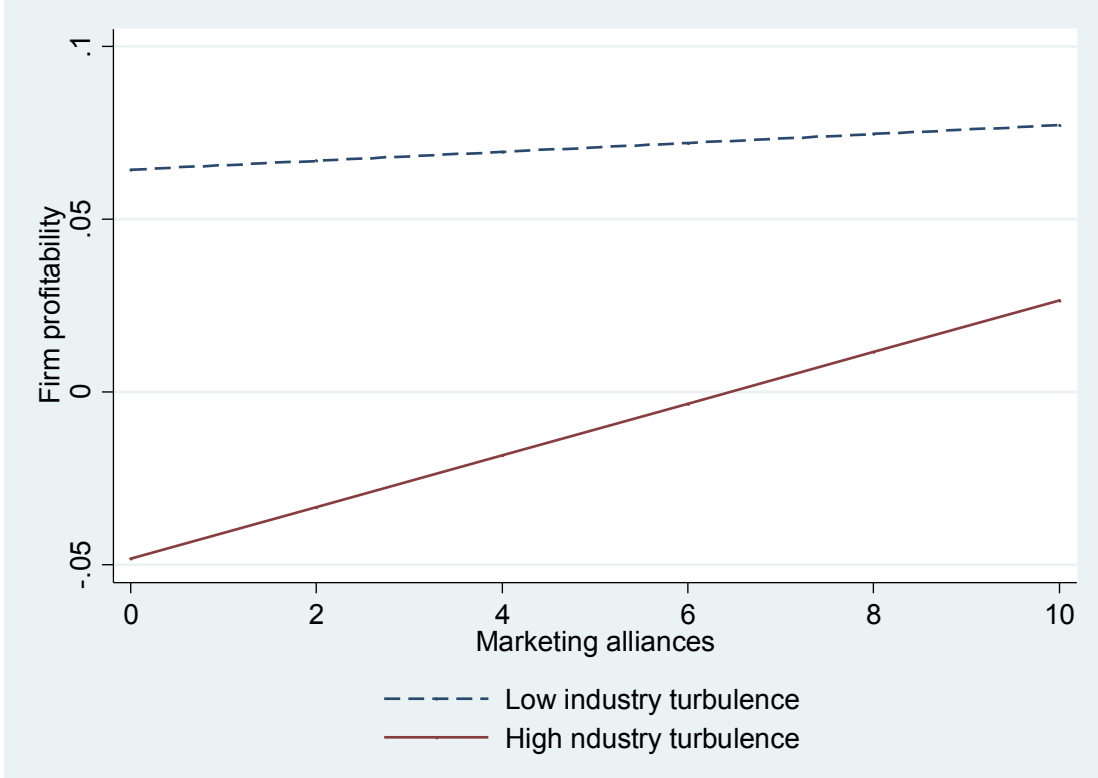

profitability is contingent upon internal and exVI. Discussion ternal factors, specifically, R\&D intensity and industry turbulence.

Table 2 further shows that firm size has a negative effect on firm profitability $(\beta=-0.032$, $p<0.05)$. In terms of direct effect of industry turbulence, Model 1 shows that it has a negative effect on firm profitability $(\beta=-0.386$, $p<0.001$ ), which makes sense in that firms may face a greater difficulty in more dynamically changing environment. Model 1 further shows that $R \& D$ intensity has a negative on firm profitability $(\beta=-0.048, p<0.05)$. However, the main results in Model 2 confirm that it enhances firm profitability by interacting with marketing alliances.

\subsection{Theoretical and managerial implications}

The findings of this study contribute to the relationship marketing literature and also provide managerial implications to marketing managers. First, this study contributes to the previous marketing alliance studies by investing boundary conditions for the benefits of forming more marketing alliances. The results of this study further imply that internal investments in R\&D magnify the effect of marketing alliances on firm profitability. That is, internal investments and alliance formation in 
the complementary tasks (i.e., R\&D and marketing) help each other in determining a firm's financial performance (Hoang and Rothaermel 2010). This study shows that simply forming more marketing alliances may not be enough to enhance firm profitability. These findings offer alternative explanations regarding the mixed findings about the effect of marketing alliances on firm performance.

Second, this study examines marketing alliances in the diverse high-tech industrial contexts, while previous studies focused on a specific industry, such as the biotechnology and pharmaceutical industries (Swaminathan and Moorman 2009; Wuyts, Dutta, and Stremersch 2004). This study extends previous findings about the boundary conditions for the benefits of marketing alliances on the financial performance of firms to a broader context, which includes semiconductors, computers, telecommunication equipment, and software industries. This study demonstrates that forming marketing alliances contributes to firm profitability in the diverse high-tech industrial contexts.

Finally, this study provides important managerial implications for building marketing alliances in the high-tech industries. The findings of this study suggest that firms should consider both environmental and internal resource investment characteristics when forming marketing alliances. In particular, firms need to consider forming more marketing alliances as a strategic choice in a dynamically changing environment. Forming more marketing alliances becomes a way to overcome the risks associated with turbulent environment and allows firms to be more effective in performing marketing activities to improve firm performance. At the same time, forming marketing alliances becomes more effective for firms that invest internal resources in R\&D activities intensively. Namely, firms need to invest internal resources in R\&D to effectively use marketing alliances for their profitability.

\subsection{Limitations and future research}

Our study is not without limitations. First, we focused on three specific internal and $\mathrm{ex}^{-}$ ternal factors (i.e., R\&D intensity and industry turbulence and competitiveness) that may moderate the effect of marketing alliances on firm profitability. Future research can examine more diverse factors that can facilitate or hinder the creation of firm profit through marketing alliances. Second, although we focused on ROA as a firm's profitability to test how marketing alliances affect the efficiency in using its assets to generate profits. However, future research can examine more diverse profitability measures, such as return on equity or return on invested capital, as they have different implications on firm performance (Damodaran 2007). Third, we counted marketing alliances that a firm initiated in the past. However, alliances can vary in terms of their importance or 
quality. By considering these heterogeneities of marketing alliances, future research can provide more nuanced findings on the benefits of marketing alliances. Finally, while this study focused on boundary conditions for the benefits of forming more marketing alliances, it will provide a promising opportunity to examine boundary conditions for the benefits of other types of alliances, such as R\&D, manufacturing, or procurement alliances. Comparison of these different types of alliances will provide more insights in terms of both theories and managerial practices to effectively use those alliances to enhance firm profits.

〈Received June 9. 2014〉

〈Accepted December 27. 2014〉

\section{References}

Aiken, L.S. and S.G. West (1991), Multiple Regression: Testing and Interpreting Interaction. Newbury Park, CA: Sage.

Anand, Bharat N. and Tarun Khanna (2000), "The Structure of Licensing Contracts," The Journal of Industrial Economics, 48 (1), 103-35.

Anderson, Erin and Weitz Barton (1992), “The Use of Pledges to Build and Sustain Commitment in Distribution Channels," Journal of Marketing Research, 29 (1), 18-34.

Bae, Jonghoon and Martin Gargiulo (2004),
"Partner Substitutability, Alliance Network Structure, and Firm Profitability in the Telecommunications Industry," Academy of Management Journal, 47 (6), 843-59.

Bello, Daniel C., Constantine S. Katsikeas, and Matthew J. Robson (2010), "Does Accommodating a Self-Serving Partner in an International Marketing Alliance Pay Off?," Journal of Marketing, 74 (6), 77-93.

Bonner, Joseph M. and Orville C. Walker (2004), "Selecting Influential Business-to-Business Customers in New Product Development: Relational Embeddedness and Knowledge Heterogeneity Considerations," Journal of Product Innovation Management, 21 (3), 155-69.

Bucklin, Louis P. and Sanjit Sengupta (1993), "Organizing Successful Co-Marketing Alliances," Journal of Marketing, 57 (April), 32-46.

Cui, Anna Shaojie, David A. Griffith, and S. Tamer Cavusgil (2005), "The Influence of Competitive Intensity and Market Dynamism on Knowledge Management Capabilities of Multinational Corporation Subsidiaries," Journal of International Marketing, 13 (3), 32-53.

Damodaran, Aswath (2007), "Return on Capital (Roc), Return on Invested Capital (Roic) and Return on Equity (Roe): Measurement and Implications," Working paper.

Das, Somnath, Pradyot K. Sen, and Sanjit Sengupta (1998), “Impact of Strategic Alliances on Firm Valuation," Academy of Management Journal, 41 (1), 27-41. 
Dickinson, Sonia and Tara Heath (2006), “A Comparison of Qualitative and Quantitative Results Concerning Evaluations of $\mathrm{Co}^{-}$ Branded Offerings," Journal of Brand Management, 13 (6), 393-406.

Dwyer, F. Robert and Sejo Oh (1987), "Output Sector Munificence Effects on the Internal Political Economy of Marketing Channels," Journal of Marketing Research, 24 (4), 347-58.

Ellegaard, Chris, Christopher Medlin, and Jens Geersbro (2014), "Value Appropriation in Business Exchange - Literature Review and Future Research Opportunities," Journal of Business \& Industrial Marketing, 29 (3), 185-98.

Fabrizio, Kira R. and L. G. Thomas (2012), "The Impact of Local Demand on Innovation in a Global Industry," Strategic Management Journal, 33 (1), 42-64.

Fang, Eric (2008), "Customer Participation and the Trade-Off between New Product Innovativeness and Speed to Market," Journal of Marketing, 72 (4), 90-104.

Fang, Eric, Robert W. Palmatier, and JanBenedict E. M. Steenkamp (2008), "Effect of Service Transition Strategies on Firm Value," Journal of Marketing, 72 (5), 1-14.

Golder, Peter N. and Gerard J. Tellis (1993), "Pioneer Advantage: Marketing Logic or Marketing Legend?," Journal of Marketing Research, 30 (2), 158-70.

Grewal, Rajdeep and Patriya Tansuhaj (2001),
"Building Organizational Capabilities for Managing Economic Crisis: The Role of Market Orientation and Strategic Flexibility," Journal of Marketing, 65 (2), 67-80.

Hagedoorn, John (1993), "Understanding the Rationale of Strategic Technology Partnering: Interorganizational Modes of Cooperation and Sectoral Differences," Strategic Management Journal, 14 (July), 371-85.

Hausman, J. A. (1978), "Specification Tests in Econometrics," Econometrica, 46 (6), 125171.

Hoang, H. and F. T. Rothaermel (2010), "Leveraging Internal and External Experience: Exploration, Exploitation, and R\&D Project Performance," Strategic Management Journal, 31 (7), 734-58.

Houston, Mark B. and Shane A. Johnson (2000), "Buyer-Supplier Contracts Versus Joint Ventures: Determinants and Consequences of Transaction Structure," Journal of Marketing Research, 37 (1), 1-15.

Jap, Sandy D. (1999), “'Pie-Expansion’ Efforts: Collaboration Processes in Buyer-Supplier Relationships," Journal of Marketing Research, 36 (4), 461-75.

Jaworski, Bernard J. and Ajay K. Kohli (1993), "Market Orientation: Antecedents and Consequences," Journal of Marketing, 57 (3), 53-70.

Kalaignanam, Kartik, Venkatesh Shankar, and Rajan Varadarajan (2007), “Asymmetric New Product Development Alliances: Win- 
Win or Win-Lose Partnerships?," Management Science, 53 (3), 357-74.

Kale, Prashant, Jeffrey H. Dyer, and Harbir Singh (2002), "Alliance Capability, Stock Market Response, and Long Term Alliance Success: The Role of the Alliance Function," Strategic Management Journal, 23 (8), 74767.

King, David R., Rebecca J. Slotegraaf, and Idalene Kesner (2008), "Performance Implications of Firm Resource Interactions in the Acquisition of R\&D-Intensive Firms," Organization Science, 19 (2), 327-40.

Koh, Jeongsuk and N. Venkatraman (1991), "Joint Venture Formation and Stock Market Reactions: An Assessment in the Information Technology Sector," Academy of Management Journal, 34 (4), 869-92.

Kohli, Ajay K and Bernard J Jaworski (1990), "Market Orientation: The Construct, Research Propositions, and Managerial Implications," The Journal of Marketing, 1-18.

Lavie, Dovev and Stewart R. Miller (2008), "Alliance Portfolio Internationalization and Firm Performance," Organization Science, 19 (4), 623-46.

Lee, Jongkuk (2011), "The Alignment of Contract Terms for Knowledge-Creating and Knowledge-Appropriating Relationship Portfolios," Journal of Marketing, 75 (4), 11027.

Lin, Chih-Pin and Hsin-Mei Lin (2009), "Maker-Buyer Strategic Alliances: An
Integrated Framework," Journal of Business \& Industrial Marketing, 25 (1), 43-56.

Luo, Xueming, Aric Rindfleisch, and David K. Tse (2007), "Working with Rivals: The Impact of Competitor Alliances on Financial Performance," Journal of Marketing Research, 44 (1), 73-83.

Moorman, Christine and Rebecca J. Slotegraaf (1999), "The Contingency Value of Complementary Capabilities in Product Development," Journal of Marketing Research, 36 (2), 239-57.

Podolny, Joel M. (2001), "Networks as the Pipes and Prisms of the Markets," American Journal of Sociology, 107 (July), 33-60.

Sivadas, Eugene and F. Robert Dwyer (2000), "An Examination of Organizational Factors Influencing New Product Success in Internal and Alliance-Based Processes," Journal of Marketing, 64 (January), 31-49.

Song, Michael, Cornelia Droge, Sangphet Hanvanich, and Roger Calantone (2005), "Marketing and Technology Resource Complementarity: An Analysis of Their Interaction Effect in Two Environmental Contexts," Strategic Management Journal, 26 (3), 259-76.

Stuart, Toby E. (2000), “Interorganizational Alliances and the Performance of Firms: A Study of Growth and Innovation Rates in a High-Technology Industry," Strategic Management Journal, 21 (8), 791-811.

Swaminathan, Vanitha and Christine Moorman (2009), "Marketing Alliances, Firm Networks, 
and Firm Value Creation," Journal of Marketing, 73 (5), 52-69.

Venkatesh, R., Vijay Mahajan, and Eitan Muller (2000), "Dynamic Co-Marketing Alliances: When and Why Do They Succeed or Fail?," International Journal of Research in Marketing, 17 (1), 3-31.
Wooldridge, J. (2002), Econometric Analysis of Cross Section and Panel Data. Cambridge, MA: MIT Press.

Wuyts, Stefan, Shantanu Dutta, and Stefan Stremersch (2004), "Portfolios of Interfirm Agreements in Technology-Intensive Markets: Consequences for Innovation and Profitability," Journal of Marketing, 68 (2), 88-100. 